\title{
Evaluasi Pengembangan Coaching Pelatihan Dasar Calon Pegawai Negeri Sipil Lingkup Provinsi Sulawesi Tenggara Angkatan XCV, XCVI, dan XCVII Tahun 2021
}

\author{
Evaluation of Coaching Development in Basic Training of Civil Servant \\ Candidates in The Province of Southeast Sulawesi Batch XCV, XCVI, and \\ XCVII 2021
}

\author{
Sahabuddin \\ Badan Kepegawaian Daerah Kota Gorontalo, Jl. Jenderal Panjaitan No. 357, Kota Gorontalo \\ karaeng71262@gmail.com
}

\begin{abstract}
Naskah diterima tanggal 10 Mei 2021. Naskah direvisi tanggal 4 Juni 2021.
Naskah disetujui tanggal 5 Juni 2021.
\end{abstract}

\begin{abstract}
Abstrak
Tujuan penelitian ini adalah untuk mengevaluasi (membandingkan antara seharusnya dan praktik yang terjadi) praktik coaching yang dilaksanakan dalam Pelatihan Dasar Calon Pegawai Negeri Sipil Angkatan XCV, XVI dan XCVII Lingkup Pemerintah Daerah Provinsi Sulawesi Tenggara Tahun 2021. Dari hasil penelitian diperoleh hasil antara lain: Penunjukan coach pada Pelatihan Dasar Calon Pegawai Negeri Sipil Angkatan XCV, XVI dan XCVII selama ini adalah penugasan pembimbingan peserta Latsar dengan label "coach", penunjukan coach belum didasari atas kejelasan kompetensi dan kualifikasi. Pemahaman para coach terhadap aspek-aspek coaching selama ini masih lemah, baik coach maupun peserta masih belum bisa membedakan antara coaching, mentoring, dan konseling karena sebelum penugasan dan pelaksanaan pembimbingan mereka tidak pernah mendapatkan penjelasan dan pengarahan tentang coaching, mentoring, dan konseling secara mendalam, dan mereka baru menjadi coach sejak adanya Latsar. Sebagian besar coach belum memiliki keterampilan coaching yang semestinya. Sebagian besar coach melakukan penggalian kompetensi peserta yang bersifat teknis dari persoalan yang dihadapi peserta dan hampir setengah dari mereka melakukan penggalian kompetensi peserta yang bersifat adaptif. Hal itu terjadi karena selama ini mereka kurang mendapat penjelasan dan pelatihan bagaimana membedakan antara coaching dan mentoring peserta Pelatihan Dasar CPNS.
\end{abstract}

Kata kunci: Coaching; Mentoring; Konseling; Kompetensi dan kualifikasi coach; Model dan teknik coaching

\footnotetext{
Abstract

The purpose of this research is to evaluate (comparing of the compulsion and the practice) of coaching practice performed in the basic training of civil servant candidates batch XCV, XCVI, and XCVII in the province of Southeast Sulawesi year 2021. From the result, it is
} 
obtained that the coach election in the basic training of civil servant candidates batch XCV, $X C V I$, and XCVII is the assignment of supervising the participants of basic training labelled "coach", which the coach election is not based of the competencies and qualification clarity. The coaches understanding over the coaching aspects is considered weak, both coaches and participants who have not understood of how to differ coaching, mentoring, and counselling because before the assignment and the implementation of supervision, they never received the explanation and briefing about coaching, mentoring, and counselling deeply, besides they have just been a coach since the basic training being held. Most coaches have not had capable coaching skills. Most of them identify participants competence technically from problems they face and almost half of them identify the participants competence adaptively. It happens because they obtain less explanation and training on how to differ coaching from mentoring in the basic training of civil servant candidates.

Keywords: Coaching, Mentoring, Counselling, Coach's competencies and qualifications, Coaching model and techniques

\section{PENDAHULUAN}

\section{Latar Belakang}

Sejalan dengan telah ditetapkannya Undang-Undang Nomor 5 Tahun 2014 tentang Aparatur Sipil Negara (UU ASN) dan merujuk pada ketentuan Pasal 63 ayat (3) dan ayat (4) UU ASN, CPNS wajib menjalani masa percobaan yang dilaksanakan melalui proses pelatihan terintegrasi untuk membangun integritas moral, kejujuran, semangat dan motivasi nasionalisme dan kebangsaan, karakter kepribadian yang unggul dan bertanggungjawab, dan memperkuat profesionalisme serta kompetensi bidang. Diperlukan sebuah penyelenggaraan pelatihan yang inovatif dan terintegrasi, yaitu penyelenggaraan pelatihan yang memadukan pembelajaran klasikal dan nonklasikal di tempat pelatihan dan di tempat kerja, sehingga memungkinkan peserta mampu menginternalisasi, menerapkan, dan mengaktulisasikan, serta membuatnya menjadi kebiasaan (habituasi), dan merasakan manfaatnya, sehingga terpatri dalam dirinya sebagai karakter PNS yang profesional sesuai bidang tugas. Melalui pembaharuan pelatihan tersebut, diharapkan dapat menghasilkan PNS profesional yang berkarakter dalam melaksanakan tugas dan jabatannya sebagai pelaksana kebijakan publik, pelayan publik, dan perekat dan pemersatu bangsa.

Menghadapi tantangan tersebut, perlu meningkatkan daya saing baik nasional maupun regional. PNS sebagai pelayan masyarakat yang mempunyai peranan penting dalam proses pelayanan publik dalam masyarakat, merupakan aset negara yang perlu dikembang potensi dan kemampuannya. Untuk mewujudkan hal itu, diperlukan desain diklat yang tepat bagi CPNS sebagai awal pembentukan karakter dan kompetensi sesuai tuntutan jabatannya. Berdasarkan hal di atas, penyempurnaan dan pengayaan konsep Diklat Prajabatan dilakukan 
dengan mengembangkan desain diklat terintegrasi sejalan dengan perkembangan dinamika tuntutan jabatan dan penguatan terhadap kompetensi bidang sesuai dengan formasi jabatan yang ditetapkan. Setelah diberlakukannya UU ASN, nomenklatur Diklat Prajabatan diubah menjadi Pelatihan Dasar CPNS sebagai salah satu pelatihan strategis dalam rangka pembentukan karakter PNS dan kemampuan bersikap dan bertindak profesional mengelola tantangan dan masalah keragaman sosial-kultural dengan menggunakan perspektif whole of government atau one government. yang didasarkan pada nilai-nilai dasar PNS berdasarkan kedudukan dan peran PNS dalam Negara Kesatuan Republik Indonesia (NKRI) pada setiap pelaksanaan tugas jabatannya sebagai pelayan masyarakat sebagai wujud nyata bela negara seorang PNS dan untuk mengwujudkan hal tersebut diperlukan proses coaching peserta Pelatihan Dasar yang didukung oleh kompetensi coach yang sesuai dengan syarat kualifikasi yang sesuai dengan harapan peserta Pelatihan Dasar CPNS.

Dalam kurikulum Pelatihan Dasar CPNS, tersedia pembelajaran berupa pembimbingan (coaching dan mentoring) yang dilakukan selama pelaksanaan Pelatihan Dasar CPNS yang terdiri atas a) Pembimbingan di kelas b) Pembimbingan di tempat kerja dan c) konseling. Hal ini perlu didukung dengan tersedianya tenaga coach, mentor, dan konselor yang memiliki tugas dan peran yang berbeda. Dari hasil observasi Agus Dwiyanto $\underline{(2015)}$ terhadap praktik coaching selama ini diperoleh gambaran sebagai berikut:

a. Pemahaman widyaiswara terhadap fungsi coaching berbeda-beda (terjadi tumpang tindih peran antara coach dan mentor sehingga membingungkan peserta karena adanya arahan/pendapat yang berbeda antara coach dan mentor);

b. Sebagian besar widyaiswara menempatkan dirinya lebih superior, knowledgeable, dsb. dari peserta Pelatihan Dasar CPNS. Hubungan antara coach dengan peserta seperti hubungan antara atasan dan bawahan (Super Coach);

c. Banyak widyaiswara yang memusatkan perhatian pada hal teknis, seperti pembimbing tesis, dengan mempersoalkan judul, teknis penulisan, wording, dsb.;

d. Sebagian widyaiswara mengabaikan perannya sebagai motivator, sumber inspirasi, dan provokator untuk memberi tantangan kepada peserta untuk mengerahkan semua kemampuannya dalam mengelola inovasi yang diciptakannya.

Di sisi lain, penulis sering melihat dan mendengar laporan hasil akhir Pelatihan Dasar CPNS sebagian peserta yang dinyatakan lulus tertunda disebabkan nilai yang berkaitan dengan Laporan Aktualisasi Nilai Dasar ANEKA belum mencapai batas minimal sehingga 
yang bersangkutan harus menyempurnakan/memperbaiki laporannya sesuai batas waktu yang diberikan oleh penyelenggara dan memenuhi syarat kelulusan seorang peserta pelatihan dasar.

Dari gambaran keadaan di atas, penulis ingin melihat lebih jauh dengan mengkaji dan mengetahui sejauh mana pelaksanaan coaching pada peserta Pelatihan Dasar CPNS Golongan III Angkatan XCV, XCVI dan XCVII Tahun 2021 yang beberapa bulan yang lalu dilaksanakan oleh Badan Pengembangan Sumber Daya Manusia Provinsi Sulawesi Tenggara.

\section{Rumusan Masalah Penelitian}

Berdasarkan uraian pada latar belakang tersebut di atas maka rumusan masalah dalam penelitian ini adalah:

a. Bagaimana gambaran praktik coaching pada peserta Pelatihan Dasar CPNS Golongan III Angkatan XCV, XCVI, dan XCVII yang berlangsung pada Tahun $2021 ?$

b. Kompetensi apa saja yang harus dimiliki oleh seorang coach yang akan melakukan coaching?

\section{Tujuan dan Manfaat}

a. Tujuan Penelitian

Berdasarkan latar belakang yang penulis kemukakan di atas maka tujuan yang ingin dicapai adalah untuk mengetahui gambaran pelaksanaan coaching pada pelaksanaan Pelatihan Dasar CPNS Golongan III Angkatan XCV, XCVI, dan XCVII Tahun 2021.

b. Manfaat

Hasil Penelitian ini diharapkan dapat memberikan manfaat berupa sumbangan pemikiran menyangkut penunjukan coach pada Pelatihan Dasar CPNS di masa yang akan datang. 


\section{TINJAUAN PUSTAKA}

Untuk menjawab beberapa pertanyaan pada pokok permasalahan di atas, diperlukan beberapa teori, konsep, dan metodologi antara lain:

\section{Pedoman Coaching, Konseling, dan Mentoring dalam Pelatihan Dasar CPNS}

Sesuai dengan Peraturan Lembaga Administrasi Negara Nomor 12 Tahun 2018 tentang Pelatihan Dasar CPNS yang dimaksud dengan:

a. Pembimbingan di kelas

Kegiatan Pembelajaran ini membekali peserta dengan penjelasan tentang metode coaching, mentoring, dan pelaksanaan komitmen bersama untuk membangun komitmen antara peserta dengan mentor dan pemangku kepentingan terkait dalam menentukan area proyek perubahan.

b. Pembimbingan di tempat kerja

Pada kegiatan pembelajaran ini peserta menentukan area proyek perubahan dan mengimplementasikan rancangan proyek perubahan bersama mentor dan coach melalui pembimbingan.

c. Konseling

Kegiatan ini diberikan kepada peserta yang mengalami permasalahan interpersonal. Peserta akan dibekali kemampuan untuk membangun motivasi diri dalam melaksanakan tahap Membangun Komitmen Bersama melalui konsultansi peningkatan motivasi dalam menerapkan tahap tersebut di tempat tugas.

d. Pembimbing (Coach dan Mentor)

1) Pembimbing (coach) adalah widyaiswara/pegawai lainnya yang memiliki kompetensi dalam menggali potensi peserta untuk melaksanakan proyek perubahan.

2) Pembimbing (mentor) adalah atasan langsung peserta yang memiliki kompetensi dalam memberikan dukungan, bimbingan, dan masukan kepada peserta untuk melaksanakan proyek perubahan.

3) Konselor adalah pengajar yang memiliki kompetensi dalam memberikan motivasi, saran, dan masukan yang bersifat psikologis kepada peserta diklat yang membutuhkan. 


\section{Teori dan Konsep Praktik Coaching}

\section{A. Beberapa pengertian:}

Karl Inge Tangen (2011) menjelaskan, bahwa Coaching adalah sebuah fenomena menarik karena beberapa alasan. Pertama, coaching adalah cara baru yang mengemuka, belakangan ini menjadi semakin lebih populer pada organisasi modern. Dalam konteks ini bahwa David Logan (2004) telah memproklamirkan revolusi coaching (coaching revolution). Kedua, konsep coaching kehidupan (life coaching) belakangan ini juga cenderung menguat dan tampaknya menyebar dengan globalisasi pada individualisme modern.

Gary Collins dalam Karl Inge Tangen (2011) menjelaskan tentang makna coaching yaitu sebagai mencatat, menarik. Dari tahun 1500-an dan seterusnya, kata coaching dijelaskan sebagai kendaraan yang ditarik kuda. Dari sekitar 1880, kata coaching diberi makna atletik, mengidentifikasi orang yang mengajari pendayung di Cambridge University untuk pindah dari satu tempat ke tempat yang lain. Jadi gambaran dari coach-sport yang datang bersama seseorang (atau tim) untuk membantu orang berpindah dari satu tempat ke tempat lain, mungkin dapat digunakan sebagai metafora mendalam, atau akar-metafora dari praktik coaching. Kemudian cukup didefinisikan, praktik coaching adalah dimana satu orang datang bersama yang lain untuk membantu dia mencapai tujuan tertentu. Sampai di sini mungkin berguna, namun, perlu untuk memperjelas perbedaan antara coaching kehidupan (life coaching) dan pembinaan kinerja (performance coaching). Julie Kennedy (2009) menjelaskan ada banyak kategori coaching seperti:

1) Coaching Kehidupan/Life coaching (menentukan dan mencapai tujuan pribadi)

2) Coaching Bisnis: (memberikan dukungan kepada individu atau kelompok dalam rangka meningkatkan efektivitas bisnis mereka)

3) Coaching Pribadi (kesepakatan antara coach dan klien berdasarkan minat, tujuan dan sasaran yang dinyatakan klien)

4) Coaching Kesehatan (manajemen kesehatan dan penyakit)

5) Coaching Olahraga (meningkatkan teknik dan kinerja)

6) Coaching Hubungan/Relationship Coaching (meningkatkan keberhasilan dalam kencan dan hubungan)

7) Konflik Coaching (pernikahan atau lainnya di mana klien belajar untuk meningkatkan keterampilan manajemen konflik dan kemampuan)

8) Coaching Project (manajemen tim) 
9) Coaching Situasional (peningkatan kinerja sesuai konteks)

10) Coaching Transisi (antara pekerjaan atau peran)

11) Coaching Pendidikan (meningkatkan keberhasilan akademis atau hubungan keluarga), dan lain-lain.

\section{B. Prinsip Dasar Coaching}

Marilyn Atkinson (2016), pendiri Erickson Coaching International menjelaskan bahwa untuk memahami coaching dengan benar ada baiknya untuk memahami apa itu: training, coaching, mentoring, consulting, counselling, dan therapy.

Coaching vs Mentoring: Mentor adalah seorang ahli yang memberikan hal-hal bijak dan membimbing berdasarkan pengalaman sendiri. Mentor dapat menasihati, melakukan konseling dan coaching. Proses coaching tidak termasuk menasihati atau konseling dan berfokus pada kemampuan individu atau kelompok dalam menetapkan dan mencapai tujuan mereka sendiri. Selaras dengan pernyataan tersebut, The Chartered Institute of Personnel and Development (CIPD) dalam mengelaborasi perbedaan antara coaching dan mentoring.

Coaching vs Counselling: Tidak seperti terapis dan konselor, coaching tidak fokus pada masa kanak-kanak atau pengalaman masa lalu yang mungkin menjadi dasar dari perasaan atau cara hidup seseorang saat ini. Sebaliknya mereka membantu kliennya untuk mendapatkan kejelasan tentang apa yang mereka inginkan di masa depan, mengapa mereka menginginkannya, dan bagaimana mereka akan mencapainya.

Coaching vs Training: Pelatihan didasarkan pada tujuan yang ditetapkan oleh pelatih atau instruktur. Meskipun tujuan dijelaskan dalam proses coaching, hal itu ditetapkan oleh individu atau tim yang dicoach, dengan bimbingan dari coach. Pelatihan juga melakukan jalur pembelajaran linear yang bertepatan dengan kurikulum yang sudah ditetapkan. Coaching kurang linear dan tanpa kurikulum yang ditetapkan.

Dari persamaan dan perbedaan tersebut, secara prinsip keseluruhannya dapat dilihat pada gambar 4 sebagai berikut: 


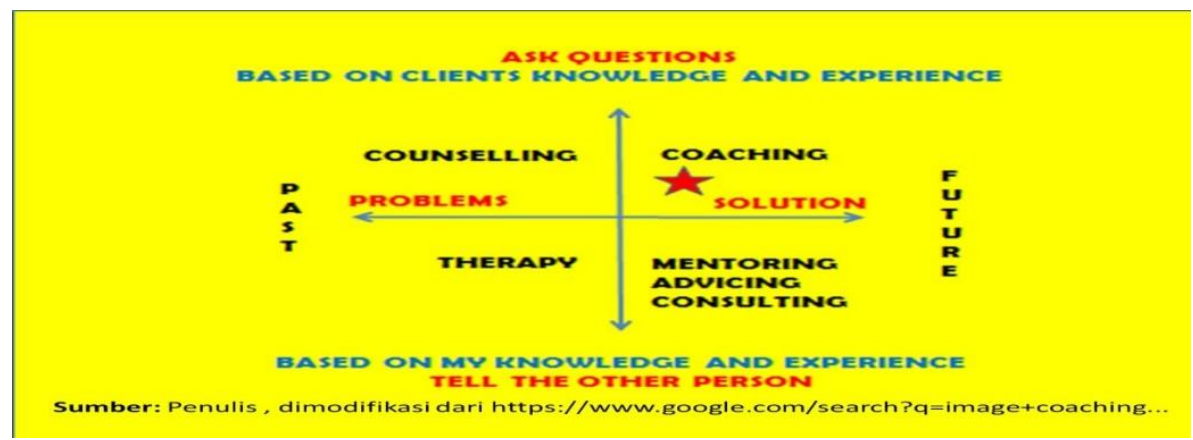

Gambar 4. Perbedaan Coaching, Konseling, dan Mentoring

Dari penjelasan dan gambar di atas dapat diidentifikasi beberapa prinsip dasar coaching, antara lain:

1) Coaching adalah bertanya, berdasarkan pengetahuan dan pengalaman klien (coaching is ask questions based on client's knowledge and experience),

2) Coaching adalah fokus kepada solusi di masa depan (getting solution for the future)

Untuk menjadi coach yang sukses, sebelum kita dapat melakukan coach kepada klien kita untuk mencapai tingkat kinerja terbaik, kita perlu memahami berbagai penghalang yang menyebabkan mereka tidak bisa berubah dari keadaannya sekarang.

\section{Praktik Dasar Coaching}

Williams dan Davis (2003) mendefinisikan tentang praktik dasar coaching dan kebajikan terkait. Dalam model coaching, coach diberikan peran utama sebagai mitra dalam percakapan dengan kehidupan klien (orang yang di-coach). Apa yang dilakukan oleh coach sebagai partner? Menurut Williams dan Davis (2003) praktik utama seorang coach pada tingkat dasar adalah mendengarkan dan memberitahu kebenaran dalam empat langkah yang sudah dipersiapkan, yaitu:

1) Mendengarkan dan minta penjelasan,

2) Merefleksikan apa yang didengar,

3) Mendengarkan lebih banyak, dan

4) Meminta tindak-lanjut (requests action).

Coach terutama harus mendengarkan apa yang ingin dicapai dan diwujudkan oleh klien. Coach harus mencari dan mengidentifikasi tujuan dan kekuatan, memberi pujian dan mendukung klien, dan pada saat yang sama juga mendengarkan kesenjangan antara keinginan dan realitas klien. Dalam proses ini, coach lebih fokus pada solusi (solution 
focused) daripada terapi, dalam arti bahwa coach mencari peluang/kemungkinan bukan menemukan masalahnya, riwayatnya, sindromnya, atau hambatan psikologisnya. Apa yang dimaksud dengan mengatakan yang sebenarnya? Mengatakan yang sebenarnya adalah tentang menunjukkan potensi ketidak-sesuaian atau intuisi tentang problem-area, dan menunjukkan kekuatan klien. Untuk menjadi catatan disini, apa yang tidak termasuk dalam mengatakan yang sebenarnya, misalnya tidak mengkonfrontasikan dan lebih penting lagi seorang coach yang baik adalah mendengarkan untuk/dengan agenda klien, bukan agenda yang dipikirkan oleh coach dan mengarahkannya kepada klien. Bagi para coach, hal ini mutlak penting, untuk tidak melakukan dan menolak segala bentuk konseling dan dan percakapan yang mengarahkan.

Gary Collins dalam Karl Inge Tangen (2011) memberikan review tentang coaching sebagai berikut: Dari banyak buku coaching yang tersedia menunjukkan bahwa sebagian besar penulis menekankan kemampuan klien untuk "melihat kedalam" dengan bantuan coach mereka, untuk mendengarkan nilai-nilai, tujuan dan visi yang jauh di dalam, untuk fokus pada kekuatan batin, dan untuk menemukan gairah mereka dan tujuan hidup. Tidak ada yang absolut dan aturan-aturan dalam berfikir. Namun, ada baiknya diperhatikan bahwa mendengarkan adalah cara menperoleh solusi, menurut Williams dan Davis (2003) mendengarkan untuk mempeoleh solusi adalah cara menghilangkan hambatan besar untuk menjadi coach yang hebat, karena hal itu menghambat proses yang kuat dalam penemuan, penggalian, dari ide-ide kreatif yang berasal dari percakapan coaching. Hal terakhir ini penting karena idealnya orang yang di-coach (klien) tidak sekedar memiliki visi yang diberikan tapi dia juga pada akhirnya harus menciptakan sendiri. Jadi coaching, adalah praktek menyiapkan pemberdayaan atau bertujuan untuk menyediakan jenis tertentu kebebasan, dalam hal penciptaan diri sendiri, atau jika orang menghendakinyai, aktualisasidiri (self-actualization). Kebebasan di sini berarti kemampuan untuk menetapkan tujuan hidup sendiri secara holistik dan kemampuan untuk mencapai tujuan tersebut. Pendekatan dan perspektif ini merupakan nilai penting dalam paradigma peningkatan keterampilan dan praktek coaching sebagaimana ditegaskan dan dipromosikan oleh Williams dan Davis (2003):

a. Permintaan maksud tertentu (purposeful inquiry), yang pada dasarnya berarti untuk bergerak bersama-sama, dipandu oleh rasa ingin tahu (curiosity); 
b. Jangan pernah membuat salah kepada klien, yang berarti bahwa coach harus fokus pada apa yang klien butuhkan, dan bukan pada apa yang coach pikirkan atau perlukan;

c. Berpikir kemungkinan, yang berarti untuk melihat dan mendorong pemikiran berani dan positif dari klien;

d. Standing for, yang berarti -mengingatkan mimpi klien mereka dan percaya pada kemungkinan mewujudkannya;

e. Membingkai kembali, yang berarti membantu klien untuk melihat situasi dari perspektif baru dan berbeda;

f. Penggunaan metafora dan perumpamaan untuk merangsang imaginasi klien.

\section{Kompetensi Coach}

Alison Carter (2006) menjelaskan coaching sebagai alat yang efektif dalam peningkatan kapasitas pegawai dalam organisasi dapat dilakukan dengan menggunakan tiga cara, yaitu:

1. Menggunakan Coach-Specialist dari dalam organisasi,

2. Menciptakan budaya coaching gaya manajemen (dikenal sebagai: atasan sebagai coach),

3. Menggunakan Eksekutif-Coach dari luar organisasi.

Lebih jauh, Alison menjelaskan bahwa kualitas kemampuan coach berkontribusi sangat signifikan terhadap hasil coaching. Efek dari kualitas dan keterampilan coach dianggap lebih berpengaruh dalam coching dibandingkan dengan peran pembimbing dalam kegiatan pelatihan tradisional. Hal ini menunjukan bahwa efektivitas setiap intervensi coaching terutama ditentukan oleh kemampuan coach.

Sejalan dengan Alison, Julie Kennedy (2009) mengatakan, bahwa banyak orang memiliki kapasitas untuk menjadi coach namun untuk menjadi coach yang sangat baik dan efektif dibutuhkan beberapa keterampilan (skills), kualitas (qualities) dan pola pikir (mindset). Keterampilan adalah sesuatu yang harus dipelajari, kualitas lebih melekat namun bagaimanapun perlu diperkuat dan diperdalam, dan pola pikir adalah kerangka pikiran dimana coach akan bekerja. Ketiga hal tersebut saling berhubungan, kualitas dapat diperoleh dan diperkuat, kualitas dalam beberapa hal adalah keterampilan. Berikut ini beberapa hal yang penting dari ketiganya:

1. Keterampilan, berkaitan dengan; 
a) Mendengarkan untuk memahami.

b) Bertanya yang menimbulkan kesadaran

c) Penguasaan diri

d) Pemahaman struktur

e) Membangun hubungan (komunikasi)

f) Mengamati hubungan pola pikir dan perilaku klien

g) Memberikan umpan balik

h) Melakukan tahap pengembangan dan kredibilitas

i) Meningkatkan keterampilan

2. Pola pikir (Mindset), berkaitan dengan;

Pola pikir adalah bingkai yang lebih besar dari pikiran di mana kualitas dan keterampilan dapat beroperasi :

a. Semua orang memiliki dalam diri mereka potensi yang sangat besar

b. Kita masing-masing memiliki pandangan yang unik tentang realitas

c. Orang-orang pada dasarnya baik

d. Kita masing-masing bertanggung jawab atas hasil yang kita dapatkan dalam hidup

Seorang coach adalah fasilitator, bukan guru. Seorang coach adalah motivator yang mendukung tujuan klien. Seorang coach percaya bahwa solusi ada pada setiap orang, jadi seorang coach tidak akan memberikan ilmu/solusi tertentu tapi mengajukan pertanyaanpertanyaan untuk menggali, sehingga seseorang (client/coachee) bisa menemukan solusinya sendiri. Coach menjadi cermin, membantu, dan memberi saran kepada klien untuk melakukan pekerjaan yang dibutuhkan; menyelesaikan tugas jabatan/kepemimpinan, proyek-proyek, dst.

Biasanya berbasis hubungan one-on-one di mana coach membantu klien untuk fokus dan mencapai tujuan-tujuannya lebih cepat dari pada klien berusaha sendirian. Coach adalah orang yang ahli dalam memfasilitasi pencapaian tujuan atau proses perkembangan diri klien, namun dia tidak perlu ahli benar dalam topik yang di-coach-nya. Coach biasanya membantu klien dengan menyediakan tools dan hal-hal yang dapat memotivasi dan membantu pencapaian tujuan klien. 


\section{F. Alat-alat (Tools) dalam Coaching.}

1) Logical Level Alignment (LLA) sebagai coaching framework.

Marilyn Atkinson (2007) menyatakan bahwa LLA menyiapkan kontek coaching yang kuat. Sebagai sebuah kerangka kerja LLA akan melatarbelakangi proses dan tahapan coaching yang kita lakukan, kita akan melihat:

a. Hubungan coaching dapat dibangun pada tingkatan logika yang berbeda;

b. Tingkat berpikir logis dapat dicermati dalam setiap kalimat dari setiap orang. Tingkat berpikir seseorang akan ditunjukkan dalam cara mereka menggunakan nada dan kata-kata kunci;

c. Kita dapat menggunakan tingkat berpikir untuk mempertimbangkan permasalahan ketika seseorang bingung atau sedang tidak menentu.

Hubungan coaching dapat dibangun pada tingkatan logika yang berbeda. Untuk mengawali proses coaching dan percakapan yang baik, kita dapat memulai dengan mencocokkan (menggambarkan dan melengkapi aspek lain) pencocokan bisa terjadi pada setiap tingkatan logika;

2) Lingkungan (Environment): pada level ini biasanya berkaitan dengan tampak luar dan berasal dari kebiasaan klien, misalnya berasal dari daerah yang sama atau bekerja untuk organisasi yang sama. Kita juga dapat mencocokkan harapan seperti cara berpakaian dan penampilan (misal: di beberapa organisasi jika kita tidak mengenakan seragam kerja pada saat bekerja, kita segera akan kehilangan kredibilitas);

3) Kemampuan (Capabilities): pada level ini hubungan dapat dibangun pada kepentingan bersama (menjalankan organisasi, kelompok olah raga, pramuka, dsb.) dan keterampilan bersama (kelompok coaching, pengacara, atau asosiasi sosial, dsb.);

4) Nilai-nilai (Values): pada level ini hubungan dapat dibangun dengan menghormati dan memahami keyakinan dan nilai-nilai dari orang lain. anda tidak perlu setuju dengan mereka; Namun anda harus menghormati apa yang penting bagi mereka.

5) Identitas (Identity): untuk mendapatkan hubungan pada tingkat identitas anda perlu memahami dan menghormati core belief dan nilainilai orang lain, dan memperhatikan mereka secara pribadi. Menunjukkan minat yang tulus tentang "siapa mereka", berbagi beberapa core belief dan nilai-nilai pribadi anda akan sangat mendukung hubungan pada tingkat ini.

6) Melebihi Identitas (Beyond Identity:Vision/Spiritual): Tingkat ini sejalan dengan core belief lainnya untuk berkontribusi sesuatu yang lebih besar selain kepada dirinya sendiri 
(kegiatan sosial). Ini adalah tentang budaya bersama. Pada tingkat spiritual, ini adalah tentang mengenali anda sebagai bagian dari kemanusiaan, dan kita semua saling berhubungan. Hal ini dimungkinkan untuk memiliki hubungan di beberapa tingkat, tetapi tidak dengan yang lain. Secara umum, semakin jauh anda naik tingkatan, semakin besar tingkat hubungan yang akan anda capai. Terjadi ketidakcocokan pada tingkat yang lebih tinggi mengakibatkan rusaknya hubungan yang telah dibangun pada tingkat yang lebih rendah.

\section{METODE PENELITIAN}

Penelitian ini adalah penelitian Mixed Methods, sesuai yang dikemukakan oleh Cavaye (1996) bahwa dalam suatu penelitian studi kasus dapat menggabungkan dua moetode melalui wawancara mendalam dengan melakukan anlisis kualitatif terhadap isu-isu spesifik yang kemudian dijadikan variabel terukur.

\section{a. Lokasi dan Waktu Penelitian}

Evaluasi ini dilakukan pada Penyelenggaraan Pelatihan Dasar CPNS Golongan III Lingkup Pemerintah Provinsi Sulawesi Tenggara Angkatan XCV, XCVI dan XCVII yang dilaksanakan oleh Badan Pengembangan Sumber Daya Manusia Provinsi Sulawesi Tenggara pada tahun 2021.

\section{b. Macam/ Sifat Penelitian}

Dilihat dari sifatnya penelitian ini bersifat deskriptif analisis, karena memberikan gambaran tentang pelaksanaan coaching peserta Pelatihan Dasar CPNS dan selanjutnya memberikan rekomendasi tentang bagaimana pelaksanaan coaching yang seharusnya dilaksanakan pada peserta Pelatihan Dasar CPNS untuk memberikan sumbangan peningkatan kualitas aktualisasi nilai dasar aparatur sipil negara di Pemerintah Daerah Provinsi Sulawesi Tenggara.

\section{c. Teknik Pengumpulan Data}

Untuk memperoleh data yang akan dibutuhkan dalam kajian ini, penulis menggunakan beberapa metode pengumpulan data sebagaimana layaknya yang dilakukan dalam proses penelitian yaitu :

1) Observasi: adalah kemampuan seseorang untuk menggunakan pengamatannya melalui hasil kerja pancaindra mata serta dibantu dengan pancaindra lainnya. Dalam penelitian ini digunakan observasi partisipasi (participant observer) yaitu 
pengumpulan data melalui observasi terhadap objek pengamatan dengan langsung hidup bersama, merasakan serta berada dalam aktivitas kehidupan objek pengamatan (Bungin, 2009: 115, 116). Adapun data yang dikumpulkan melalui obeservasi adalah hasil wawancara yang dilakukan penulis pada peserta Pelatihan Dasar CPNS Golongan III Angkatan XCV , XCVI, dan XCVII.

2) Kuesioner: adalah pertanyaan tertulis yang diberikan kepada responden untuk dijawab. Responden dapat memberikan jawaban dengan memberi tanda pada salah satu atau beberapa jawaban yang telah disediakan, atau dengan menuliskan jawabannya (Kountur, 2007: 189). Peneliti menggunakan kuesioner ini sebagai alat pengumpulan data yang paling utama yang akan dikembangkan lebih lanjut. Data yang dikumpulkan adalah peran coach dalam melakukan coching pada peserta Pelatihan Dasar CPNS Angkatan XCV , XCVI dan XCVII masing-masing kelas berjumlah 20 (dua puluh) orang.

3) Wawancara: adalah cara pengumpulan data yang dilakukan dengan bertanya dan mendengarkan jawaban langsung dari sumber utama data. Peneliti merupakan pewawancara dan sumber data adalah orang yang diwawancarai. (Kountur, 2007: 186). Selanjutnya untuk mendalami permasalahan yang dibahas dalam penelitian ini mengenai peran coach dalam melakukan coching pada peserta Pelatihan Dasar CPNS Angkatan XCV , XCVI dan XCVII, maka digunakan wawancara sebagai alat bantu tambahan.

\section{d. Metode Analisis Data}

Teknik analisis data yang digunakan dalam penelitian ini adalah analisis-deskriftif mengenai peran coach dalam melakukan coaching pada peserta Pelatihan Dasar CPNS. Proses ini dimulai dengan mengumpulkan seluruh data yang diperoleh baik melalui hasil observasi, kuesioner dan bantuan wawancara, kemudian dideskripsikan dengan menggunakan analisis persentase. Untuk menghitung persentase jawaban yang diberikan responden, kemudian penulis mencari hasil persentase menggunakan rumus seperti yang dikemukakan Hartono (1999) adalah sebagai berikut:

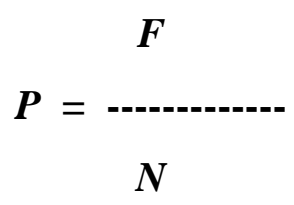

Dimana :

$\mathrm{P}=$ Persentase 
$\mathrm{F}=$ Prekwensi yang sedang dicari presenteasenya ( frekwensi jawaban)

$\mathrm{N}=$ Jumlah responden

Dalam penafsiran data digunakan metode penafsiran data sebagaimana di kemukakan oleh Supardi (1997). Penafsiran data menggunakan dua angka dibelakang koma, sebagai berikut :

$\begin{array}{lll}0,00 \% & = & \text { Tidak ada } \\ 0.01 \%-24,99 \% & = & \text { Sebagian Kecil } \\ 25 \%-49,99 \% & = & \text { Hampir setengah } \\ 50 \% & =\text { Setengahnya } \\ 50,01 \%-74,99 \% & =\text { Sebagian besar } \\ 75 \%-99,99 \% & =\text { Pada umumnya } \\ 100 \% & =\text { Seluruhnya }\end{array}$

Setelah dibuat prosentase, selanjutnya data ditampilkan dalam bentuk matriks dan diintreprestasikan menggunakan analisis kuantitatif dengan menggunakan metode deduktif dan induktif sesuai dengan kebutuhan.

\section{HASIL DAN PEMBAHASAN}

\section{Mekanisme Penunjukan/Penetapan Coach}

Coaching adalah kegiatan integratif dalam pelaksanaan Pelatihan Dasar CPNS, oleh karena itu keberadaan coach bersama-sama dengan mentor sebagai atasan langsung peserta dan unsur lainnya akan sangat berpengaruh terhadap peluang kelulusan peserta Latsar CPNS, sebagaimana dijelaskan dalam Keputusan Kepala Lembaga Administrasi Negara Nomor 12 Tahun 2018 bahwa pembimbing merupakan pengajar yang memiliki kompetensi untuk memfasilitasi pembelajaran agenda habituasi di tempat kerja.

Mengacu pada Keputusan Kepala Lembaga Administrasi Negara tersebut di atas, seyogyanya coach yang akan ditugaskan oleh penyelenggara adalah seorang pengajar. Pembimbing terdiri atas coach dan mentor dimana coach berada pada lembaga pendidikan yang memiliki kompetensi menggali potensi pengembangan diri peserta pelatihan dasar dalam melaksanakan pembelajaran agenda habituasi. Dari uraian tentang peran coach tersebut di atas diperlukan seorang coach yang memiliki pengalaman tugas melaksanakan proses coaching disamping itu pula harus memiliki pengalaman kerja sebagai mentor yang melekat pada seseorang karena memiliki tanggung jawab sebagai pejabat struktural dan 
pernah mengikuti pendidikan dan pelatihan terkait bagaimana proses coaching itu seharusnya dilakukan.

Klasifikasi coach yang ada pada Badan Pengembangan Sumber Daya Manusia Provinsi Sulawesi Tenggara dapat dilihat pada tabel berikut :

Tabel 1

Klasifikasi Coach pada Penyelenggaraan Pelatihan Dasar CPNS

\begin{tabular}{|l|c|c|c|c|}
\hline & $\begin{array}{c}\text { Pernah/sedang } \\
\text { menduduki } \\
\text { jabatan } \\
\text { struktural }\end{array}$ & $\begin{array}{c}\text { Pernah } \\
\text { mengikuti } \\
\text { Diklatpim }\end{array}$ & $\begin{array}{c}\text { Pernah ToF/ } \\
\text { Workshop } \\
\text { Coaching }\end{array}$ & $\begin{array}{c}\text { Mengampu } \\
\text { Mata } \\
\text { Pelatihan } \\
\text { Latsar CPNS }\end{array}$ \\
\hline Kategori I & Ya & Ya & Ya & Ya \\
\hline Kategori II & Tidak & Tidak & Ya & Ya \\
\hline Kategori III & Ya & Ya & Ya & Tidak \\
\hline
\end{tabular}

Sumber: Hasil Analisis Kuesioner

Dari tabel tersebut di atas, dapat dianalisis adanya kesenjangan kompetensi coach, ini ditujukan berdasarkan hasil kuesioner sehingga adanya kesenjangan kualifikasi, hal tersebut ditunjukkan masih ada coach yang ditugaskan oleh Penyelenggara yang tidak mengampu mata pelatihan Latsar CPNS sehingga akan berpengaruh terhadap kualitas proses coaching. Sebagaimana yang telah diatur dalam Peraturan Lembaga Administrasi Negara Nomor 12 tahun 2018 tentang Pelatihan Dasar Calon Pegawai Negeri Sipil.

Dari hasil analisis di atas dapat dikemukakan bahwa:

a. Coach pada Pelatihan Dasar CPNS saat ini adalah penugasan pembimbingan peserta Pelatihan Dasar CPNS dengan label coach;

b. Penunjukan coach selama ini belum jelas kompetensi dan kualifikasinya yang akan berpengaruh terhadap kualitas proses coaching;

c. Saat ini belum ada panduan yang mengatur dan menetapkan kompetensi dan kualifikasi coach pada Pelatihan Dasar CPNS.

\section{Pemahaman Aspek Coaching dan Praktik Coaching}

Sebagaimana djelasakan pada bab pendahuluan yang dikemukakan oleh Marilyn Atkinson (2016), bahwa pemahaman terhadap aspek coaching menjadi prasyarat utama untuk melakukan coaching. Hal tersebut menjadi sangat penting karena pemahaman aspek coaching akan membedakan dalam praktik antara coaching dengan yang lainnya, seperti mentoring, konseling, dan consulting, untuk mengukur tingkat pemahaman tentang coaching 
dari para coach dalam Pelatihan Dasar digunakan pengukuran dengan lima aspek, yaitu proses, hubungan, struktur, fokus dan penggunaan alat diagnostik.

Dari hasil evaluasi diperoleh prosentase pemahaman para coach tentang coaching sebagaimana dapat dilihat pada tabel berikut :

\section{Tabel 2}

Prosentase Pemahaman Coach terhadap aspek Coaching

\begin{tabular}{|c|c|c|}
\hline \multicolumn{2}{|r|}{ Pemahaman Aspek Coaching } & Prosentase \\
\hline \multirow[t]{2}{*}{ 1. Proses } & $\begin{array}{l}\text { a. Pada saat melakukan coaching berusaha } \\
\text { memahami pengetahuan yang ada pada } \\
\text { peserta }\end{array}$ & 52,8 \\
\hline & $\begin{array}{l}\text { b. Pada saat coaching lebih banyak bertanya } \\
\text { terlibat mencari tau dalam memandu peserta }\end{array}$ & 47,2 \\
\hline 2. Hubungan & $\begin{array}{l}\text { c. Hubungan antara coach dan peserta } \\
\text { cenderung memposisikan peserta sebagai } \\
\text { mitra bukan bawahan }\end{array}$ & 40,5 \\
\hline 3. Struktur & $\begin{array}{l}\text { d. Struktur coaching yang diterapkan selama } \\
\text { Pelatihan Dasar CPNS teratur sesuai } \\
\text { kesepakan bersama. }\end{array}$ & 57,2 \\
\hline 4. Fokus & $\begin{array}{l}\text { e. Fokus perhatian selama coaching berlansung } \\
\text { diarahkan pada penyelesaian masalah } \\
\text { peserta }\end{array}$ & 43,5 \\
\hline $\begin{array}{l}\text { 5. Alat } \\
\text { Diagnostik }\end{array}$ & $\begin{array}{ll}\text { f. } & \text { Dalam melakukan coaching senantiasa } \\
\text { menggunakan alat diagnistik berupa daftar } \\
\text { pertanyaan, kuisener serta lembar observasi }\end{array}$ & 15,5 \\
\hline
\end{tabular}

Sumber : Penulis, diolah dari kuesioner dan hasil wawancara

Dari tabel di atas dapat diperoleh informasi :

1) Aspek Proses: lebih dari setengah atau 52,8\% coach pada proses coaching berusaha memahami pengetahuan yang ada pada peserta kemudian kurang dari setengah atau 47,2 \% pada proses coaching lebih banyak bertanya dan terlibat dalam mencari tahu dalam memandu peserta;

2) Aspek Hubungan: Hampir setengah atau 40,5\% coach pada saat hubungan antara coach dan peserta cenderung melakukan kemitraan;

3) Aspek Struktur: Lebih dari setengah atau 57,2\% coach melakukan coaching secara terstruktur yakni waktu disepakati dan dijadwalkan yang merupakan komitmen bersama; 
4) Aspek Fokus: Hampir setengah atau 43,5\% coach melakukan coach dengan fokus perhatian pada membangun penyelesaian masalah yang menjadi prioritas

5) Aspek Penggunaan alat diagnostik: sebagian kecil atau 15,5\% coach melakukan coaching dengan menggunakan alat diagnostik seperti daftar pertanyaan, kuesioner, dan lembar observasi.

Dari hasil wawancara dan obeservasi diperoleh informasi sebagian coach dan peserta banyak yang belum mendapatkan penjelasan tentang aspek-aspek saja yang harus diperhatikan dalam praktik coaching, walaupun ada beberapa coach yang berusaha sendiri untuk memahami dan memelajari tentang coaching dari berbagai literatur. Dari informasi uraian di atas dapat ditarik kesimpulan bahwa pemahaman para coach terhadap aspek-aspek coach selama ini masih rendah, baik coach atau peserta masih belum paham membedakan antara coaching, mentoring dan consulting (Marilyn Atkinson, 2016). Karena sebelum penugasan dan pelaksanaan bimbingan mereka tidak pernah mendapatkan penjelasan dan pengarahan tentang coaching, mentoring, dan consulting secara mendalam sementara mereka harus menjadi coach karena adanya penugasan dari pimpinan.

\section{Keterampilan coaching selama proses coaching.}

Pemahaman dan keterampilan coaching sulit di bedakan karena bagaikan dua sisi mata uang saling berkaitan satu sama lain. Keterampilan coaching adalah sesuatu yang bisa dipelajari harus diawali dengan pemahaman tentang coaching, dan pada akhirnya akan menentukan kualitas coaching.

Bagaimana gambaran coaching sebagai ilmu dapat dipelajari oleh setiap orang sebagai coach saat ini dapat kita lihat pada tabel berikut :

\section{Tabel 3}

Prosentase coach yang memiliki keterampilan coaching

\begin{tabular}{|l|l|c|c|}
\hline \multirow{2}{*}{ No } & \multicolumn{1}{|c|}{ Keterampilan Coach } & \multicolumn{2}{c|}{ Prosentase Coach } \\
\cline { 3 - 4 } & $\begin{array}{c}\text { Sudah } \\
\text { Memiliki } \\
\text { Keterampilan }\end{array}$ & $\begin{array}{c}\text { Belum } \\
\text { memiliki } \\
\text { Keterampilan }\end{array}$ \\
\hline 1 & $\begin{array}{l}\text { Bertanya hal-hal yang menginspirasi } \\
\text { peserta sebagai solusi persoalan yang } \\
\text { dihadapi }\end{array}$ & 54.49 \\
\hline 2 & $\begin{array}{l}\text { Bertanya pada hal-hal yang memotivasi } \\
\text { terhadap solusi persoalan yang } \\
\text { dihadapi peserta }\end{array}$ & 45.51 & \\
\hline
\end{tabular}




\begin{tabular}{|l|l|l|l|}
\hline 3 & $\begin{array}{l}\text { Bertanya pada hal-hal yang } \\
\text { memprovokasi adanya solusi dari } \\
\text { persoalan yang dihadapi peserta }\end{array}$ & & \\
\hline 4 & $\begin{array}{l}\text { Bertanya pada hal - hal yang } \\
\text { menantang terhadap solusi persoalan } \\
\text { yang dihadapi peserta }\end{array}$ & & \\
\hline 5 & $\begin{array}{l}\text { Bertanya pada hal yang fokusnya ke } \\
\text { masa depan dari persoalan yang } \\
\text { dihadapi peserta }\end{array}$ & & \\
\hline 6 & $\begin{array}{l}\text { Mendengarkan jawaban peserta dengan } \\
\text { seksama dan berusaha untuk } \\
\text { memahahaminya dengan benar }\end{array}$ & & \\
\hline 7 & $\begin{array}{l}\text { Mempertimbangkan, menguraikan dan } \\
\text { meringkas semua jawaban peserta dan } \\
\text { memberikan umpan balik }\end{array}$ & & \\
\hline
\end{tabular}

\section{Sumber : Penulis, diolah dari kuisioner}

Dari tabel di atas dapat diperoleh informasi bahwa hampir setengah atau 45,51\% coach sudah memiliki potensi keterampilan coaching berupa bertanya hal hal yang : 1) menginspirasi, 2) memotivasi, 3) memprovakasi, 4) menantang, 5) fokus ke masa depan, dari masalah yang dihadapi peserta, 6) mendengarkan jawaban peserta dengan seksama dan berusaha untuk memahaminya dengan teliti dan benar dan 7) mempertimbangkan, menguraikan, dan meringkas setiap jawaban peserta dan memberikan umpan balik. Namun sebahagian besar coach atau 54,49\% coach belum memilki potensi keterampilan coach yang seharusnya. Namun dari hampir setengahnya yang memiliki potensi belum dibingkai dalam model coaching yang seharusnya sesuai kaidah coaching yang semestinya.

Dari hasil wawancara dan observasi diperoleh informasi sebahagian besar coach belum mendapatkan pelatihan keterampilan coaching yang terinci sampai mereka memahami betul. 


\section{PENUTUP}

Coaching adalah kegiatan integratif dalam pelaksanaan Pelatihan Dasar CPNS Golongan III, bersama-sama dengan mentoring, konseling, dan unsur lainnya akan sangat berpengaruh terhadap pencapaian mutu pelatihan peserta Pelatihan Dasar CPNS. Dalam pelaksanaannya saat ini proses coaching dalam Pelatihan Dasar CPNS terkendala oleh beberapa keterbatasan, seperti: 1. Mekanisme penunjukan coach yang belum jelas kompetensi dan kualifikasinya, 2. Pemahaman coach terhadap aspek-aspek dan praktik coaching yang masih lemah, 3. Keterampilan coach selama coaching proses yang masih lemah, dan 4. Penggalian kompetensi kepemimpinan adaptif yang belum sesuai dengan konsep pelatihan yang ditelah ditetapkan.

Dari kajian "Evaluasi dan Pengembangan Model Coaching Pelatihan Dasar CPNS pada Badan Pengembangan Sumber Daya Manusia Provinsi Sulawesi Tenggara" hasilnya diuraikan pada simpulan dan diikuti dengan rekomendasi sebagai berikut:

\section{Simpulan}

a. Penunjukan coach pada Pelatihan Dasar CPNS selama ini adalah penugasan pembimbingan peserta pelatihan dasar CPNS dengan label "coach", penunjukan coach belum didasari atas kejelasan kualifikasi kompetensi, sebagaimana yang diamanatkan Peraturan Kepala Lembaga Administrasi Negara Nomor 12 Tahun 2018 tentang Pelatihan Dasar CPNS;

b. Pemahaman dan praktik coaching oleh para coach dalam Pelatihan Dasar CPNS selama ini belum sesuai dengan yang semestinya, dikarenakan sebelum penugasan mereka tidak pernah mendapatkan penjelasan dan pengarahan tentang coaching, dan mereka baru menjadi coach sejak adanya Pelatihan Dasar CPNS;

c. Sebagian coach "belum memiliki" keterampilan coaching, sehingga mengakibatkan proses coaching tidak berjalan sebgaimana mestinya.

\section{Rekomendasi}

a. Untuk mengoptimalkan proses coaching sebagai media dalam membekali, memotivasi, dan menggali kompetensi peserta Pelatihan Dasar CPNS penunjukkan sebagai coach harus didasari pada kualifikasi komptensi yang dimiliki seorang coach.

b. Untuk meningkatkan pemahaman dan keterampilan para coach dalam praktek coaching pada Pelatihan Dasar CPNS perlu segera diadakan pelatihan, penjelasan dan pengarahan tentang coaching sebelum mereka ditugaskan sebagai coach pada Latihan Dasar CPNS. 
c. Untuk meningkatkan pemahaman, menyamakan persepsi dan meningkatkan kapasitas/kompetensi para coach dalam menggali potensi yang dimiliki peserta Pelatihan Dasar CPNS, perlu segera diadakan pelatihan/workshop/lokakarya yang mampu meningkatkan pemahaman coach dan peserta dalam membedakan masalah teknis dan tantangan yang selaras dengan inovasi pada level dan scoping Pelatihan Dasar CPNS. 


\section{DAFTAR PUSTAKA}

Atkinson, M., \& Chois, R. T. (2007). The Art \& Science of Coaching: Inner Dynamics of Coaching. Radolfzell: Exalon Publishing. (1) (2) (3) (4)

Bungin, B. (2006). Penelitian Kualitatif. Jakarta: Penerbit Kencana.

Carter, A. (2006). Practical Methods for Evaluating Coaching. Brighton: Institute for Employment Studies.

Dwiyanto, A. (2015, Februari). Peran Coaching dalam Mendukung Keberhasilan Diklatpim. Sumedang, Jawa Barat.

Kementerian Pendayagunaan Aparatur Negara dan Reformasi Birokrasi. (2014). Peraturan Menteri Pendayagunaan Aparatur Negara dan Reformasi Birokrasi Nomor 22 Tahun 2014 tentang Jabatan Fungsional Widyaiswara dan Angka Kreditnya. Jakarta: Kementerian Pendayagunaan Aparatur Negara dan Reformasi Birokrasi.

Lembaga Administrasi Negara. (2018). Peraturan Lembaga Administrasi Negara Nomor 12 Tahun 2018 tentang Pelatihan Dasar CPNS. Jakarta. (1) (2) (3)

Lembaga Administrasi Negara. (2021). Peraturan Lembaga Administrasi Negara Nomor 1 Tahun 2021 tentang Pelatihan Dasar CPNS. Jakarta.

Logan, D., \& King, J. (2004). The Coaching Revolution: How Visionary Managers Are Using Coaching to Empower People and Unlock Their Full Porential. Avon: Adams Media.

MTD Training. (2010). Coaching and Mentoring. Coventry: MTD Training \& Ventus Publishing.

Passmore, J., \& Fillery-travis, A. (2011). A critical review of executive coaching research: A decade of progress and what's to come. Coaching An International Journal of Theory Research and Practice, 70-88.

Tangen, K. I. (2011). Integrating Life Coaching And Practical Theology Without Losing Our Theological Integrity. Journal of Biblical Perspectives in Leadership, 13-32. (1) $\underline{(2)} \underline{(3)}$ 